\title{
Analisis Kesalahan Siswa SD Dalam Menyelesaikan Permasalahan Luas Gabungan Bangun Datar Berdasarkan Watson's Error Category
}

\author{
Mohammad Nurwahid \\ Pascasarjana Pendidikan Matematika, Fakultas Matematika dan IPA, Universitas Negeri Malang \\ Jl. Semarang No.5, Sumbersari, Kec. Lowokwaru, Malang, Indonesia dikan \\ mohammad.nurwahid.2003118@students.um.ac.id
}

\begin{abstract}
Geometry is a branch of mathematics and is one of the subject matter in mathematics in elementary schools. Measurement of area is one of the fundamental topics in mathematics. In fact, with regard to broad measurement skills, most of the students have difficulty in describing the problem. the mistakes that students make in answering a problem or problem need to be identified, the information obtained about errors in answering math problems can be used in improving mathematics teaching and learning activities. The purpose of this study was to identify errors made in solving the broad problem of combining data shapes based on the Watson error category. This type of research is descriptive qualitative research. The subjects used were 64 th grade students of MI Nurul Huda with three different ability criteria. The selection is based on the advice of the math teacher and the daily test scores of the previous material. The results of the study show that the errors made by the research are missing conclusion errors, incorrect data errors, incorrect procedures, missing data error, and skill hierarchy problem.

Keywords: Student error, Combined area of flat shapes, Watson's error category
\end{abstract}

\begin{abstract}
Abstrak
Geometri merupakan cabang dari maᄀtematika dan menjadi salah satu materi pe $\neg$ lajaran dalam matematika di sekolah dasar. Pengukuran luas merupakan salah satu topik fundamental dalam matematika. Pada kenyataannya, berkaitan dengan keterampilan pengukuran luas, sebagian besar siswa mengalami kesulitan dalam menguraikan masalah. Kesalahan-kesalahan yang siswa lakukan dalam menjawab suatu persoalan atau permasalahan perlu diidentifikasi, karena informasi yang didapat tentang kesalahan dalam menjawab soal matematika dapat digunakan dalam meningkatkan mutu kegiatan belajar mengajar matematika. Tujuan dari penelitian ini adalah untuk mengidentifikasi kesalahan yang dilakukan siswa dalam menyelesaikan permasalahan luas gabungan bangun datar berdasarkan Watson's error category. Jenis penelitian adalah penelitian deskriptif kualitatif. Subjek yang digunakan adalah 6 siswa kelas 4 MI Nurul Huda dengan tiga kriteria kemampuan berbeda. Pemilihan subjek berdasarkan saran dari guru matematika dan nilai ulangan harian materi sebelumnya. hasil penelitian menunjukkan Kesalahan-kesalahan yang dilakukan oleh subjek penelitian adalah kesalahan kesimpulan hilang (omitted data/od), kesalahan data tidak tepat (inappropriate data/id), prosedur tidak tepat (inappropriate procedure/ip), kesalahan data hilang (omitted data/od), dan masalah hierarki keterampilan ( skills hierarchy problem/shp).
\end{abstract}

Kata kunci: Kesalahan siswa, Luas gabungan bangun datar, Watson's error category

Copyright (c) 2021 Mohammad Nurwahid

Corresponding author: Mohammad Nurwahid

Email Address: mohammad.nurwahid.2003118@students.um.ac.id

Received 12 June 2021, Accepted 02 July 2021, Published 02 July 2021

\section{PENDAHULUAN}

Matematika merupakan salah satu ilmu yang mempelajari berbagai hal yang erat kaitannya dalam kehidupan manusia, yang berperan langsung dalam aktivitas sehari-hari dalam meyelesaikan permasalahan yang dihadapi. Mempelajari matematika mampu mengembangkan cara berpikir menjadi lebih sistematis dan rapih, selain itu mempelajari matematika dapat menumbuhkan kemampuan pemecahan masalah yang sangat bermanfaat (Ariyani, 2019). Sejalan dengan hal itu, menurut Fahlevi \& Zanthy (2021) matematika memiliki peran yang sangat penting, karena matematika adalah ilmu dasar yang digunakan secara luas dalam berbagai bidang kehidupan. Pada pembelajaran matematika siswa diharapkan dapat menumbuhkan kemampuan berfikir kritis, logis, cermat, efektif dan efisien dalam memecahkan masalah. Karena pentingnya matematika ini, maka matematika perlu diajarkan mulai dari tingkat sekolah dasar sampai tingkat perguruan tinggi. Namun, mata pelajaran matematika sering 
dianggap sebagai mata pelajaran yang sulit dan menakutkan bagi siswa. Salah satu materi matematika yang sulit adalah materi geometri (Happy et al., 2019).

Geometri merupakan cabang dari maᄀtematika dan menjadi salah satu materi pe $\neg$ lajaran dalam matematika di sekolah dasar. Geometri sangat berkaitan dengan pemben $\neg$ tukan konsep yang abstrak. Pembelajaran ini tidak bisa hanya dilakukan dengan transfer penge $\neg$ tahuan atau ceramah saja, tetapi harus dila $\neg$ kukan dengan pembentukkan konsep melalui rangkaian kegiatan yang dilakukan langsung oleh siswa (Nurhasanah et al., 2017). Dalam mempelajari geometri, siswa membutuhkan suatu konsep yang matang sehingga siswa mampu menerapkan keterampilan geometri yang dimiliki seperti mevisualisasikan, mengenal bermacam-macam bangun datar dan ruang, mendeskripsikan gambar, membuat sketsa suatu bangun, melabeli titik tertentu, dan kemampuan untuk mengenal perbedaan dan kesamaan antar bangun geometri. Selain itu, di dalam memecahkan masalah geometri dibutuhkan pola berpikir dalam menerapkan konsep dan keterampilan dalam memecahkan masalah tersebut (Muhassanah et al., 2014). Menurut Siagian \& Sinaga (2019) tujuan belajar geometri adalah agar siswa memperoleh rasa percaya diri tentang kemampuan matematika (keterampilan), menjadi pemecah masalah yang baik, bisa berkomunikasi secara matematis, dan dapat bernalar secara matematis.

Dalam memahami hubungan-hubungan dian ᄀtara bangun geometri, siswa sudah diajarkan bagaimana mencari keliling dan luas bangun datar di kelas 4, pembelajaran ini berkesinam-bungan dari mulai mengidentifikasi sifat-sifat segi banyak, lalu kemudian menemukan keli-ling dan luas beberapa bangun datar (persegi, persegi panjang, segitiga, jajargenjang, tra $\neg$ pesium, belah ketupat dan layinglayang), se ᄀtelah siswa mempelajari bangun datar, siswa akan mendapatkan pembelajaran geometri kembali di kelas 5 tepatnya materi bangun ru $\neg$ ang, sehingga dalam hal ini materi keliling dan luas bangun datar menjadi prasyarat dalam mempelajari materi bangun ruang di kelas 5 (Fauzi \& Arisetyawan, 2020).

Pengukuran luas merupakan salah satu topik fundamental dalam matematika. Pengukuran luas bangun datar mengundang kajian matematika lebih lanjut dan penerapannya. Pengukuran menjadi kompetensi esensial yang dibangun di atas pengetahuan ilmiah untuk semua bidang dan karir (Smith et al., 2011). Oleh karena itu, ide pengukuran luas harus diajarkan dengan hati-hati sehingga siswa dapat memperoleh pemahaman konseptual yang baik tentang menghitung luas. Pada kenyataannya, berkaitan dengan keterampilan pengukuran luas, sebagian besar siswa mengalami kesulitan dalam menguraikan masalah. Mereka tidak dapat melihat bahwa penguraian bentuk menjadi bentuk lain akan membuat luas bangun menjadi bermacam-macam dan lebih mudah untuk dihitung luasnya (Ekawati et al., 2019).

Dalam suatu pembelajaran matematika, siswa seringkali melakukan kesalahan-kesalahan, khususnya kesalahan dalam menyelesaikan suatu permasalahan. Kesalahan-kesalahan tersebut dapat disebabkan karena rendahnya pemahaman suatu konsep matematika siswa, ketidaktelitian siswa dalam menghitung, dan lain sebagainya. Menurut Watson (Sanwidi, 2018), berpendapat bahwa ada 8 jenis kriteria kesalahan siswa yang meliputi data tidak tepat (inappropriate data/id), prosedur tidak tepat (inappropriate procedure/ip), data hilang (omitted data/od), kesimpulan hilang (ommited 
conclusion/oc), konflik level respon (response level conflic/rlc), manipulasi tidak langsung (undirected manipulation/um), masalah keterampilan hirarki (skills hierarchy problem/shp), dan selain ketujuh kriteria diatas (above other/aa).

Adanya kesalahan penyelesaian dalam menjawab permasalahan matematika ini perlu diperhatikan. Kesalahan-kesalahan yang siswa lakukan dalam menjawab suatu persoalan atau permasalahan perlu diidentifikasi, karena informasi yang didapat tentang kesalahan dalam menjawab soal matematika dapat digunakan dalam meningkatkan mutu kegiatan belajar mengajar matematika dan yang akhirkan diharapkan dapat meningkatkan kemampuan dan prestasi belajar siswa dalam pembelajaran matematika. Berdasarkan uraian tersebut, peneliti tertarik untuk melakukan penelitian tentang analisis kesalahan siswa SD dalam menyelesaikan permasalahan luas gabungan bangun datar berdasarkan kategori kesalahan Watson.

\section{METODE}

\section{Setting Penelitian}

Penelitian ini termasuk ke dalam penelitian deskriptif kualitatif, yang memiliki tujuan untuk mendeskripsikan bagaimana kesalahan siswa dalam menyelesaikan permasalahan tentang luas gabungan bangun datar dan mengatagorikan jenis kesalahan siswa berdsarkan Watson's Error Category. Subjek penelitian ini adalah siswa yang telah mendapatkan materi bangun datar yaitu siswa kelas IV MI Nurul Huda Sawo yang berjumlah 6 siswa. Penelitian ini dilaksanakan pada bulan Juni 2021. Pengambilan jumlah siswa tersebut merupakan saran yang diberikan oleh guru mata pelajaran di sekolah tersebut juga berdasarkan nilai ulangan harian pada materi sebelumnya.

\section{Subjek Penelitian}

Adapun subjek tersebut terdiri 2 siswa berkemampuan tinggi (S1 dan S2), 2 siswa berkemampuan sedang (S3 dan S4), dan 2 siswa berkemampuan rendah (S5 dan S6). Sedangkan instrumen tes yang diberikan yaitu dua butir soal uraian. Data yang diperoleh dari tes adalah kesalahan yang siswa lakukan dalam menjawab setiap butir soal.

\section{Teknik Analisis Data}

Teknik analisis data yang digunakan dalam penelitian ini menggunakan model analisis data Miles dan Huberman meliputi pengumpulan data, reduksi data, dan penarikan kesimpulan. Untuk melihat kesalahan siswa dalam menyelesaikan soal untuk materi luas gabungan bangun datar, data yang sudah diperoleh kemudian dianalisis menggunakan kriteria Watson dengan indikator kesalahan yang diadaptasi dari (Cahyani \& Aini, 2021) sebagai berikut:

Tabel 1. Indikator kategori kesalahan Watson

\begin{tabular}{|c|l|}
\hline Kategori kesalahan & \multicolumn{1}{c|}{ Indikator } \\
\hline Data tidak tepat (inappropriate data/id) & Tidak menggunakan data yang seharusnya dipakai \\
\cline { 2 - 2 } & Kesalahan memasukkan data ke variabel \\
\hline & Rumus atau prinsip yang digunakan tidak benar \\
\hline
\end{tabular}




\begin{tabular}{|l|l|}
\hline $\begin{array}{l}\text { Prosedur tidak tepat (inappropriate } \\
\text { procedure/ip) }\end{array}$ & Salah menafsirkan rumus \\
\cline { 2 - 3 } & Salah dalam mengoperasikan bilangan \\
\cline { 2 - 3 } & Salah dalam memberi tanda \\
\hline Data hilang (omitted data/od) & Kurang lengkap dalam memasukkan data \\
\hline Kesimpulan hilang (omitted data/od) & $\begin{array}{l}\text { Tidak menggunakan data yang sudah diperoleh untuk } \\
\text { membuat kesimpulan dari jawaban soal }\end{array}$ \\
\hline $\begin{array}{l}\text { Konflik level respon (response level } \\
\text { conflict/rlc) }\end{array}$ & $\begin{array}{l}\text { Langsung menuliskan jawaban tanpa ada alasan atau } \\
\text { cara yang logis }\end{array}$ \\
\hline $\begin{array}{l}\text { Manipulasi tidak langsung (undiect } \\
\text { manipulation/um) }\end{array}$ & $\begin{array}{l}\text { Penyelesaian proses dari tahap satu ke } \\
\text { tahap selanjutnya tidak logis }\end{array}$ \\
\hline $\begin{array}{l}\text { Masalah hierarki keterampilan (skills } \\
\text { hierarchy problem/shp) }\end{array}$ & Salah dalam menuangkan ide aljabar \\
\hline $\begin{array}{l}\text { Kesalahan selain ketujuh kriteria diatas } \\
\text { (above other/ao) }\end{array}$ & Tidak menuliskan jawaban \\
\hline
\end{tabular}

\section{HASIL DAN DISKUSI}

Analisis dilakukan pada jawaban siswa yang berisi langkah kerja atau cara penyelesaian siswa dalam menyelesaikan soal yang diberikan. Fokus utama pada proses analisis adalah mengidentifikasi jenis-jenis kesalahan siswa dalam menyelesaikan setiap butir soal. Banyak siswa yang melakukan kesalahan dan jenis - jenis kesalahan pada tiap butir soal ditunjukkan pada tabel berikut,

Tabel 2. Data kesalahan pada soal nomor 1

\begin{tabular}{|l|l|l|l|l|l|l|}
\hline Jenis Kesalahan & S1 & S2 & S3 & S4 & S5 & S6 \\
\hline Data tidak tepat (inappropriate data/id) & & & & & $\sqrt{ }$ & \\
\hline Prosedur tidak tepat (inappropriate procedure/ip) & & & & & & $\sqrt{ }$ \\
\hline Data hilang (omitted data/od) & & & & & & \\
\hline Kesimpulan hilang (omitted data/od) & & $\sqrt{ }$ & $\sqrt{ }$ & & $\sqrt{ }$ & $\sqrt{ }$ \\
\hline Konflik level respon (response level conflict/rlc) & & & & & & \\
\hline Manipulasi tidak langsung (undiect manipulation/um) & & & & & & \\
\hline $\begin{array}{l}\text { Masalah hierarki keterampilan (skills hierarchy } \\
\text { problem/shp) }\end{array}$ & $\sqrt{ }$ & & & $\sqrt{ }$ & & $\sqrt{ }$ \\
\hline Kesalahan selain ketujuh kriteria diatas (above other/ao) & & & & & & \\
\hline
\end{tabular}

Berdasarkan Tabel 2 dan 3, dapat dilihat bahwa siswa dominan melakukan jenis kesalahan kesimpulan hilang (omitted data/od). Di samping itu siswa juga melakukan kesalahan data tidak tepat (inappropriate data/id), prosedur tidak tepat (inappropriate procedure/ip), kesalahan data hilang (omitted data/od), dan kesalahan konflik level respon (response level conflict/rlc). Berdasarkan tes yang dilakukan di kelas IV MI Nurul Huda Sawo diperoleh beberapa gambaran kesalahan siswa pada saat menyelesaikan permasalahan mengenai luas gabungan bangun datar dapat dilihat pada Gambar 1.

Pada Gambar 1 dapat dilihat dari hasil pekerjaan sisiwa S1 pada soal nomor 1 tersebut siswa telah mampu untuk menyelesaikan permasalahan luas gabungan bangun datar, siswa mampu memecah bangun datar tersebut menjadi beberapa bangun datar yang lebih sederhana. Sehingga siswa dapat menghitungnya dengan baik. Akan tetapi berdasarkan hasil pekerjaan siswa tersebut siswa siswa melakukan kesalahan konflik level respon (response level conflict/rlc) berdasarkan kategori kesalahan 
menurut Watson. Siswa tidak menuliskan bagaimana cara mendapat luas bangun tersebut. Siswa hanya menghitung luas dari beberapa bangun hasil penyederhanaan dari luas bangun yang ditanyakan. Kemudian siswa langsung menyimpulkan luas bangun tersebut. Seharusnya siswa tersebut menuliskan bagaimana cara memperoleh luas bangun tersebut. Misalnya menuliskan $L_{\text {Total }}=L_{1}+L_{2}+L_{3}$.

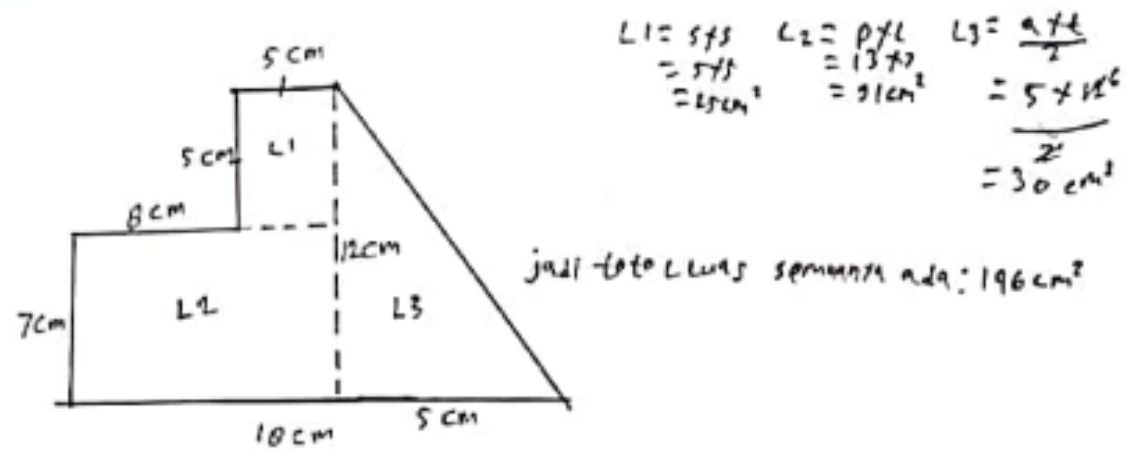

Gambar 1. Hasil pekerjaan sisiwa (S1) soal nomor 1

Sedangkan untuk soal nomor 2, siswa (S1) juga melakukan kesalahan yang sama dengan hasil pekerjaan pada soal nomor 1. Hasil pekerjaan siswa (S1) pada soal nomor 2 ditunjukkan pada gambar berikut.

\section{HiTungua cuasdati baran dibuahini!}

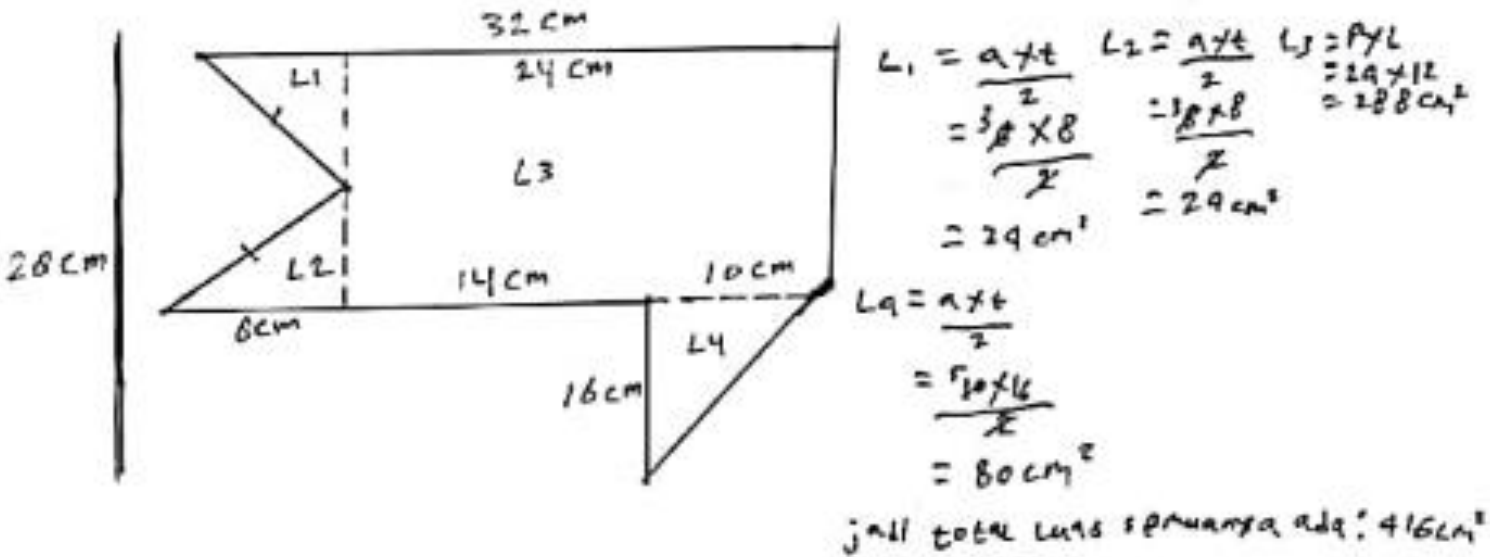

Gambar 2. Hasil pekerjaan sisiwa (S1) soal nomor 2

Pada soal nomor 2 ini, siswa (S1) mampu memecah bangun tersebut menjadi beberapa bangun yang lebih sederhana dan mampu menghitung luasnya dengan benar. Akan tetapi siswa langsung menyimpulkan luas bangun tersebut tanpa menuliskan bagaimana cara mendapatkan luas bangun tersebut. Seharusnya siswa tersebut menuliskan bagaimana cara memperoleh luas bangun tersebut. Misalnya menuliskan $L_{\text {Total }}=L_{1}+L_{2}+L_{3}+L_{4}$. Berdasarkan kategori kesalahan menurut Watson siswa (S1) dalam mengerjakan soal nomor 2 melakukan kesalahan konflik level respon (response level conflict/rlc). Sedangkan untuk hasil pekerjaan siswa (S2) ditunjukkan pada gambar berikut. 


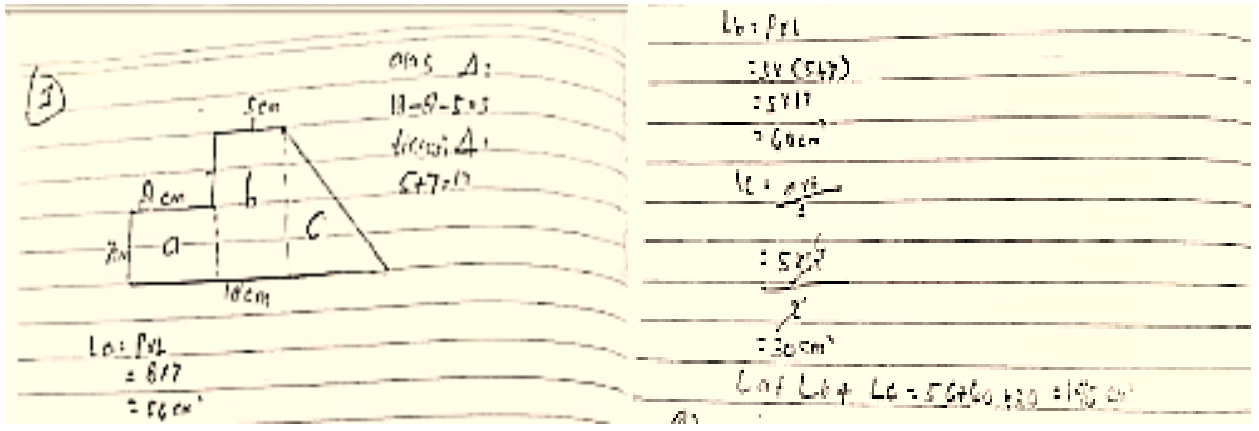

Gambar 3. Hasil pekerjaan sisiwa (S2) soal nomor 1

Berdasarkan gambar 3 tersebut, siswa (S2) melakukan prosedur dan proses yang benar. Akan tetapi siswa tersebut tidak menuliskan kesimpulan dari jawaban yang ia peroleh. Seharusnya siswa tersebut menuliskan "Jadi, luas bangun tersebut adalah $146 \mathrm{~cm}^{2}$ ". Sedangkan untuk soal nomor 2 siswa (S2) juga melakukan kesalahan yang sama yaitu kesalahan kesimpulan hilang (omitted data/od) jika dilihat berdasarkan kategori kesalahan Watson. Pada soal nomor dua ini siswa (S2) juga tidak menuliskan kesimpulan dari jawaban yang diperoleh. Selanjutnya hasil pekerjaan siswa (S3) ditunjukkan pada gambar berikut

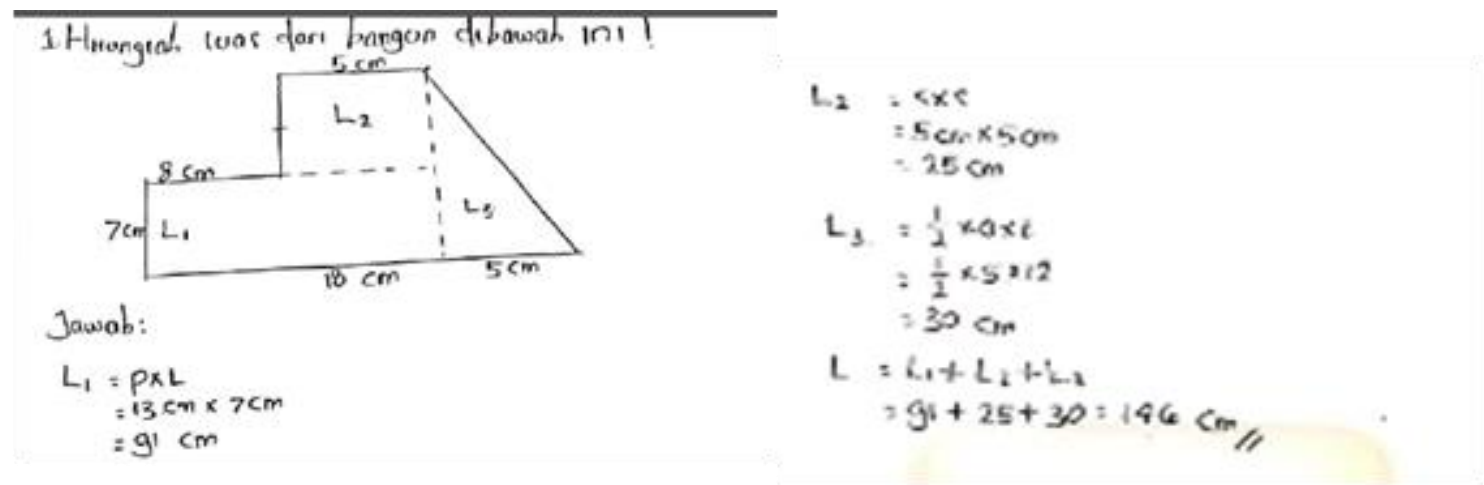

Gambar 4. Hasil pekerjaan sisiwa (S3) soal nomor 1

Berdasarkan gambar 4 tersebut siswa (S3) dalam mengerjakan soal nomor 1 melakukan kesalahan kesimpulan hilang (omitted data/od). Siswa sudah mampu memecah bangun tersebut menjadi beberapa bangun yang lebih sederhana. Siswa tersebut juga sudah menghitung dengan prosedur yang benar. Siswa tersebut juga sudah menuliskan cara memperoleh luas bangun tersebut secara keseluruhan, yaitu dengan menjumlahkn luas semua bngun yang telah dipecah $L=L_{1}+L_{2}+L_{3}$. Akan tetapi siswa tersebut tidak menuliskan kesimpulan dari jawaban yang diperoleh. Seharusnya siswa tersebut menuliskan "Jadi, luas bangun tersebut adalah $146 \mathrm{~cm}^{2}$ ". Siswa (S3) juga salah dalam menuliskan satuan luasnya. Siswa tersebut menuliskan satuan luas $\mathrm{cm}$ padahal seharusnya adalah $\mathrm{cm}^{2}$. Sedangkan untuk hasil pekerjaan siswa (S3) soal nomor 2 ditunjukkan pada gambar berikut, 


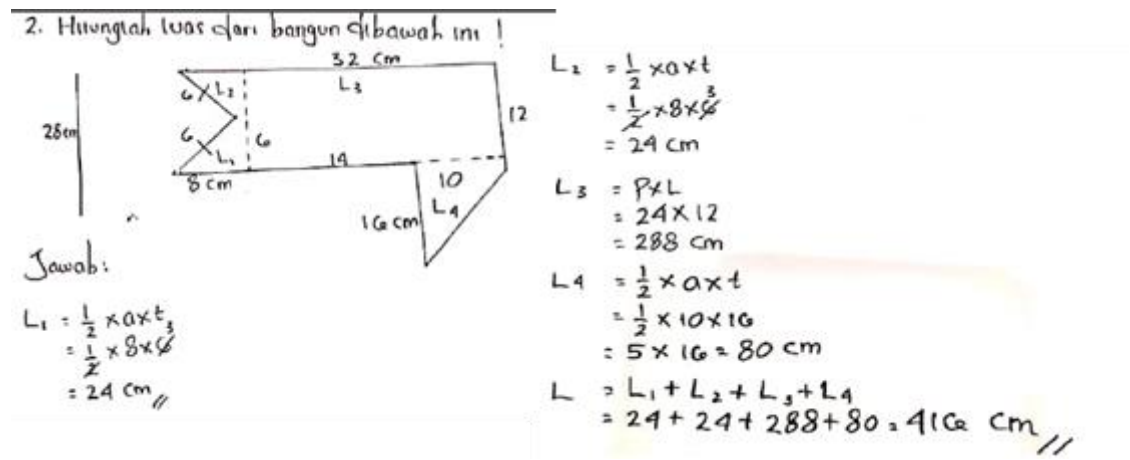

Gambar 4. Hasil pekerjaan sisiwa (S3) soal nomor 2

Berdasarkan gambar tersebt dapat dilihat bahwa siswa (S3) melakukan kesalahan kesimpulan hilang (omitted data/od). Siswa sudah mampu memecah bangun tersebut menjadi beberapa bangun yang lebih sederhana. Siswa tersebut juga sudah menghitung dengan prosedur yang benar. Siswa tersebut juga sudah menuliskan cara memperoleh luas bangun tersebut secara keseluruhan, yaitu dengan menjumlahkn luas semua bngun yang telah dipecah $L=L_{1}+L_{2}+L_{3}+L_{4}$.Akan tetapi siswa tersebut tidak menuliskan kesimpulan dari jawaban yang diperoleh. Seharusnya siswa tersebut menuliskan "Jadi, luas bangun tersebut adalah $416 \mathrm{~cm}^{2}$ ". Siswa (S3) juga salah dalam menuliskan satuan luasnya. Siswa tersebut menuliskan satuan luas $\mathrm{cm}$ padahal seharusnya adalah $\mathrm{cm}^{2}$ Sementra untuk hasil pekerjaan siswa (S4) ditunjukkan pada gambar berikut

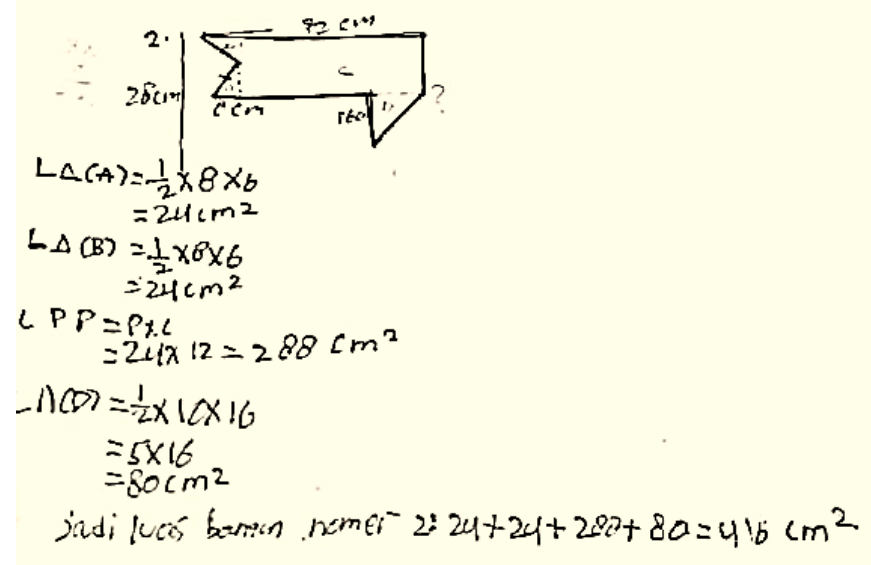

Gambar 4. Hasil pekerjaan sisiwa (S4) soal nomor 2

Berdasarkan gambar 4 tersebut siswa telah mampu untuk menyelesaikan permasalahan luas gabungan bangun datar, siswa mampu memecah bangun datar tersebut menjadi beberapa bangun datar yang lebih sederhana. Sehingga siswa dapat menghitungnya dengan baik. Akan tetapi berdasarkan hasil pekerjaan siswa tersebut siswa melakukan kesalahan masalah hierarki keterampilan (skills hierarchy problem/shp) berdasarkan kategori kesalahan menurut Watson. Kesalahan yang sama juga dilakukan pada soal nomor 1. Siswa tidak menuliskan bagaimana cara mendapat luas bangun tersebut. Siswa hanya menghitung luas dari beberapa bangun hasil penyederhanaan dari luas bangun yang ditanyakan. 
Selanjutnya siswa langsung menyimpulkan luas bangun tersebut dengan menambahkan semua hasil perhitungan dari bangun-bangun yang telah dipecah "Jadi, luas bangun nomor 2 adalah $24+24+288$ $+80=416 \mathrm{~cm}^{2}$. Seharusnya siswa tersebut menuliskan bagaimana cara memperoleh luas bangun tersebut terlebih dahulu. Misalnya menuliskan $\mathrm{L}_{\text {Total }}=\mathrm{L}_{1}+\mathrm{L}_{2}+\mathrm{L}_{3}+\mathrm{L}_{4}=24+24+288+80=416$, tidak langsung menyimpulkan dengan menjumlahkan semua hasil perhitungan yang diperoleh. Sedangkan hasil pekerjaan siswa (S5) ditunjukkan pada gambar berikut

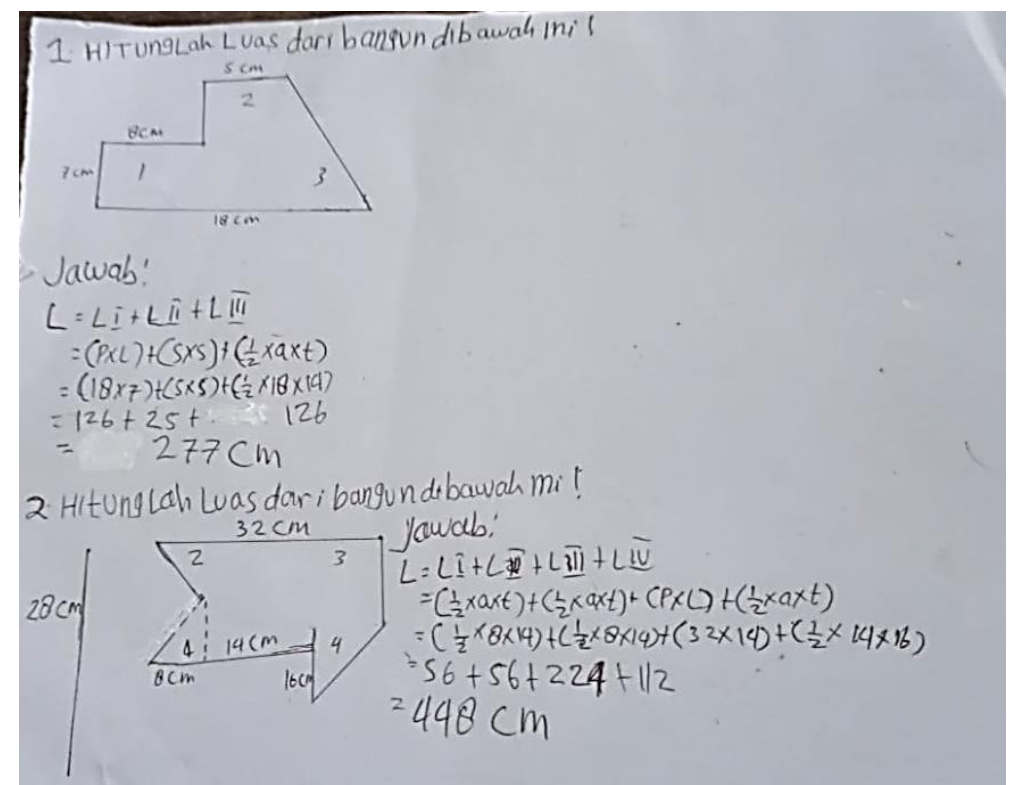

Gambar 5. Hasil pekerjaan sisiwa (S5) soal nomor 1 dan 2

Berdasarkan hasil pekerjaan siswa tersebut pada soal nomor 1siswa (S5) melakukan kesalahan data tidak tepat (inappropriate data/id). Terlihat bahwa saat menghitung $L_{1}$ yang merupakan bangun persegi panjang, siswa menuliskan $p$ nilainya 18. Padahal panjang bangun 1 adalah $8 \mathrm{~cm}$. Pada soal nomor 1 ini siswa (S5) juga melakukan kesalahan kesimpulan hilang (omitted data/od). Terlihat siswa tidak menuliskan kesimpulan dari jawaban yang diperoleh, meskipun jawaban yang diperoleh adalah salah. Siswa tidak menuliskan "Jadi, luas bangun tersebut adalah $277 \mathrm{~cm}^{2}$. Pada soal nomor 2 siswa (S5) juga melakukan kesalahan yang sama yaitu kesalahan data tidak tepat (inappropriate data/id) dan kesalahan kesimpulan hilang (omitted data/od). Hal tersebut terlihat ketika siswa mencari luas bangun 1 yang merupakan bangun segitiga. Siswa tersebut menuliskan tinggi segitiga $14 \mathrm{~cm}$, padahal seharusnya tinggi segitiga adalah $6 \mathrm{~cm}$. Kesalahan data tidak tepat juga terjadi ketika siswa mencari luas bangun 3 yang merupakan bangun persegipanjang. Siswa menuliskan panjangnya $32 \mathrm{~cm}$ dan lebarnya $14 \mathrm{~cm}$ yang seharusnya panjang persegipanjang adalah $24 \mathrm{~cm}$ dan lebarnya $12 \mathrm{~cm}$. Dalam hal ini terlihat bahwa siswa (S5) belum mampu menemukan informasi yang tidak disebutkan dalam soal. Pada soal nomor 2 ini siswa juga tidak menuliskan kesimpulan dari jawaban yang diperoleh, meskipun jawaban yang diperoleh adalah salah. Siswa tidak menuliskan "Jadi, luas bangun tersebut adalah 448 $\mathrm{cm}^{2}$ ". Sedangkan hasil pekerjaan siswa (S6) ditunjukkan pada gambar berikut, 


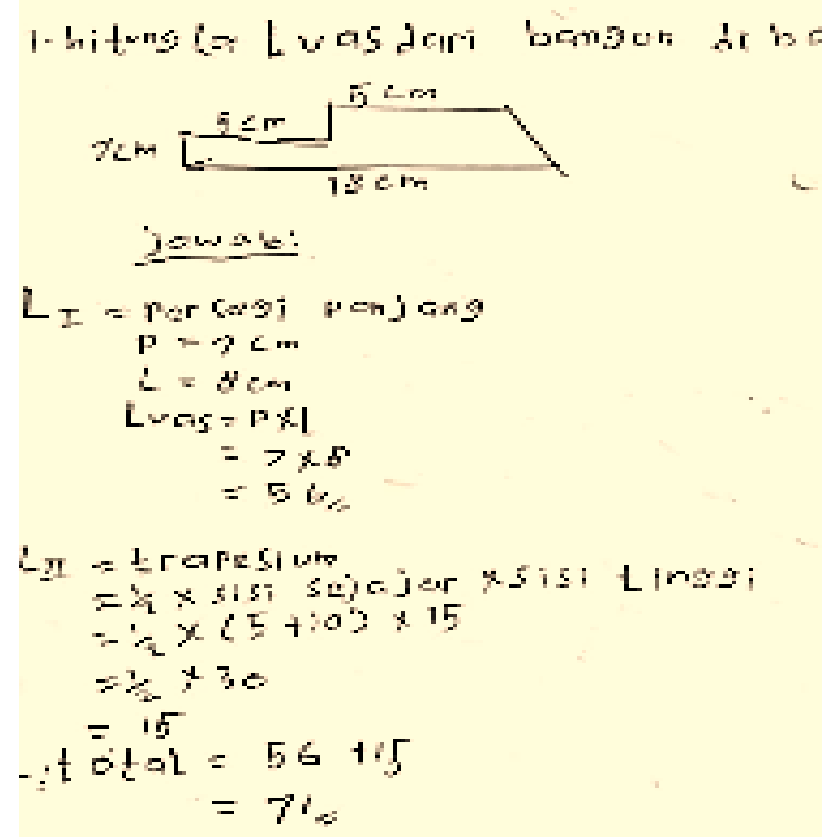

Gambar 6. Hasil pekerjaan sisiwa (S6) soal nomor 1

Berdasarkan hasil pekerjaan siswa tersebut pada soal nomor 1, siswa (S6) melakukan kesalahan prosedur tidak tepat (inappropriate procedure/ip). Hal ini terlihat ketika siswa salah dalam proses perhitungan. Dalam menghitung luas trapesium siswa (S6) menulis $=\frac{1}{2} \times(5+10) \times 15=\frac{1}{2} \times 30$, seharusnya hasil perhitungannya adalah $\frac{1}{2} \times 15 \times 15=\frac{1}{2} \times 225=112,5$. Pada soal nomor 1 ini siswa (S6) juga melakukan kesalahan masalah hierarki keterampilan (skills hierarchy problem/shp). Dalam mencari luas bangun pada soal nomor 1 , siswa langsung menuliskan $L_{\text {Total }}=56+15=71$. Seharusnya siswa tersebut menuliskan cara untuk mencari luas bangun tersebut terlebih dahulu, misalnya $L_{\text {Total }}=L_{1}+L_{2}$. Di samping hal tersebut, siswa (S6) juga melakukan kesalahan kesimpulan hilang (omitted data/od). Terlihat bahwa siswa tidak menuliskan kesimpulan dari jawaban yang diperoleh sekalipun jawaban yang diperoleh salah. Sedangkan hasil pekerjaan siswa (S3) pada soal nomor 2 ditunjukkan pada gambar berikut

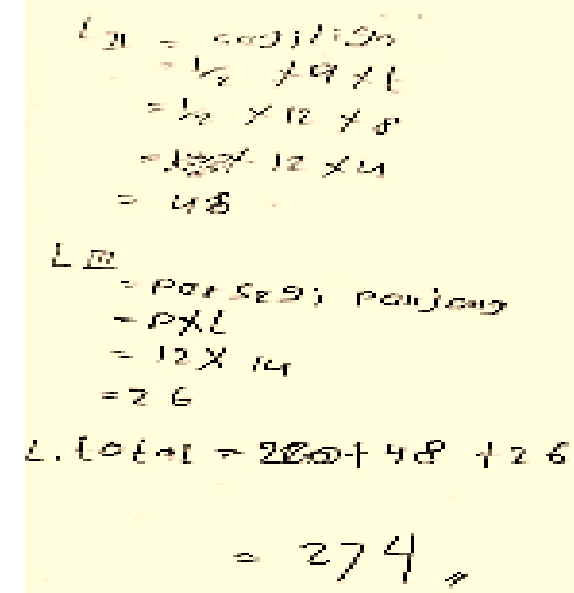

Gambar 6. Hasil pekerjaan sisiwa (S6) soal nomor 2 
Berdasarkan hasil pekerjaan siswa tersebut pada soal nomor 2, siswa (S6) melakukan kesalahan prosedur tidak tepat (inappropriate procedure/ip), data tidak tepat (inappropriate data/id), data hilang (omitted data/od). Kesalahan-kesalahan tersebut terjadi ketika siswa mencari luas bangun 2 dan luas bangun 3. Pada saat mencari luas bangun 2 terjadi kesalahan data tidak tepat. Siswa menuliskan alas segitiga $12 \mathrm{~cm}$, padahal alas segitiga yang benar adalah $6 \mathrm{~cm}$. Selanjutnya ketika mencari luas bangun 3 siswa melakukan kesalahan prosedur yaitu siswa salah dalam menghitung. Hal ini ditunjukan ketika menghitung 12 × $14=26$, seharusnya hasil yang benar dari perhitungan tersebut adalah 168 . Pada soal nomor 2 ini siswa (S6) juga melakukan kesalahan data hilang (omitted data/od). Siswa hanya menyebutkan luas segitiga satu kali, sedangkan pada soal nomor dua terdapat 2 segitiga (jika ada yang dipecah menjadi trapesium). Sehingga jawaban siswa kurang tepat. Siswa (S6) juga melakukan kesalahan kesimpulan hilang (omitted data/od). Terlihat bahwa siswa tidak menuliskan kesimpulan dari jawaban yang diperoleh sekalipun jawaban yang diperoleh salah.

Berdasarkan hasil penelitian tersebut kesalahan yang dilakukan siswa dalam menyelesaikan permasalahan luas gabungan bangun datar berdasarkan Watson's Error Category adalah kesalahan kesimpulan hilang (omitted data/od), kesalahan data tidak tepat (inappropriate data/id), prosedur tidak tepat (inappropriate procedure/ip), kesalahan data hilang (omitted data/od), dan masalah hierarki keterampilan (skills hierarchy problem/shp). Menurut Cahyani \& Aini (2021) kesalahan kesimpulan hilang (omitted data/od) terjadi disebabkan karena siswa kurang mengerti dalam mengolah data untuk mengambil kesimpulan dan siswa tidak belajar sebelum menghadapi sebuah tes. Sedangkan menurut Hariyani et al. (2019), kesalahan data tidak tepat (inappropriate data/id) terjadi karena peserta didik yang kurang memahami soal. Oleh karena itu, peserta didik tidak dapat menuliskan data atau informasi pada soal. Selain itu, peserta didik kurang teliti dalam membaca soal, sehingga data yang digunakan tidak tepat. Adapun kesalahan data hilang (omitted data/od) disebabkan karena siswa kurang teliti ketika menyelesaikan soal dan siswa kurang lengkap dalam memasukkan data (Saputri et al., 2018). Sedangkan penyebab terjadinya kesalahan masalah hierarki keterampilan (skills hierarchy problem/shp) menurut Cahyani \& Aini (2021) adalah ketidaktelitian siswa dalam mengerjiakan dan siswa merasa ragu dalam menuangkan apa yang sudah ada dalam pikirannya.

\section{KESIMPULAN}

Berdasarkan hasil penelitian dan pembahasan di atas, dapat disimpulkan bahwa subjek penelitian dalam menyelesaikan permasalahan luas gabungan bangun datar melakukan beberapa kesalahan. Jenisjenis kesalahan tersebut dianalisi berdasarkan Watson's Error Category. Kesalahan-kesalahan yang dilakukan oleh subjek penelitian adalah kesalahan kesimpulan hilang (omitted data/od), kesalahan data tidak tepat (inappropriate data/id), prosedur tidak tepat (inappropriate procedure/ip), kesalahan data hilang (omitted data/od), dan masalah hierarki keterampilan (skills hierarchy problem/shp). Subjek penelitian dengan kemampuan tinggi dan sedang melakukan kesalahan yang sama yaitu kesalahan kesimpulan hilang (omitted data/od). 
Meskipun demikian, hasil pekerjaan atau jawaban siswa dengan kemampuan tinggi dan sedang adalah benar. Hal ini menunjukkan siswa dengan kemampuan tinggi dan sedang sudah mampu menguasai konsep dan menyelesikan permasalahan luas gabungan bangun datar, hanya saja kurang dalam membuat kesimpulan akhhir. Sedangkan subjek penelitian dengan kemampuan rendah melakukan kesalahan kesimpulan hilang (omitted data/od), kesalahan data tidak tepat (inappropriate data/id), prosedur tidak tepat (inappropriate procedure/ip), dan kesalahan data hilang (omitted data/od). Hal ini menunjukkan bahwa siswa dengan kemampuan rendah belum mampu mencari informasi yang tidak diketahui pada soal sehingga siswa melakukan kesalahan dalam menjawab soal. Siswa dengan kemampuan rendah juga terlihat tidak teliti dalam melakukan perhitungan sehingga hasil jawaban yang diperoleh salah.

Saran yang dapat diberikan peneliti yaitu (1) Bagi siswa, sebaiknya sering berlatih mengerjakan soal secara mandiri untuk melatih pemahaman konsep, keterampilan menghitung, ketelitian dalam menghitung, melatih memahami maksud dari suatu permasalahan beserta membuat prosedur penyelesaian, serta siswa harus belajar dalam membuat kesimpulan akhir. (2) Bagi guru, sebaiknya dalam proses pembelajaran memberikan contoh soal dan latihan yang bervariasi untuk melatih keterampilan siswa dalam merespon permasalahan, meningkatkan keterampilan ide-ide kreatif untuk menyelesaikan soal matematika. Guru juga sebaiknya mengajak siswa untuk memeriksa jawaban dan membuat kesimpulan dari jawaban yang diperoleh. (3) Bagi peneliti lain, sebaiknya mengembangkan penelitian ini dengan melakukan penelitian lanjutan. Menggali lebih dalam lagi faktor-faktor yang mempengaruhi dan penyebab siswa melakukan kesalahan.

\section{UCAPAN TERIMA KASIH}

Peniliti ucapkan banyak terimakasih kepada semua pihak yang telah membantu dalam penelitian ini. Khususnya kepada Bapak Kepala sekolah MI. Nurul Huda Sawo yang telah memberikan ijin kepada peneliti untuk melakukan penelitian sekolahnya. Terimakasih juga peneliti ucapkan kepada guru matematika dan siswa-siswi kelas 4 MI. Nurul Huda Sawo yang telah kooperatif selama proses penelitian sehingga penelitian dapat berjalan dengan lancar.

\section{REFERENSI}

Ariyani, W. (2019). Analisis Kesalahan Matematika Siswa dalam Menyelesaikan Soal Cerita Luas Permukaan dan Volume Bangun Ruang (Kubus dan Balok) Berdasarkan Newman's Error Analysis (NEA). Journal of Matehematical Science and Mathematical Education, 01(01), 55-64. https://www.syekhnurjati.ac.id/jurnal/index.php/pmat/article/view/5067

Cahyani, A., \& Aini, I. N. (2021). Analisis Kesalahan Siswa Dalam Menyelesaikan Soal Matematika Berdasarkan Kriteria Watson. Jurnal Mathematic Paedagogic, 4(1), 12. https://doi.org/10.36294/jmp.v4i1.691 
Ekawati, R., Kohar, A. W., Imah, E. M., Amin, S. M., \& Fiangga, S. (2019). Students' cognitive processes in solving problem related to the concept of area conservation. Journal on Mathematics Education, 10(1), 21-36. https://doi.org/10.22342/jme.10.1.6339.21-36

Fahlevi, M. S., \& Zanthy, L. S. (2021). ANALISIS KESALAHAN SISWA DALAM MENYELESAIKAN SOAL MATERI BANGUN RUANG BERDASARKAN KRITERIA WATSON DITINJAU DARI PERBEDAAN GENDER SISWA SMP KELAS VIII. JPMI (Jurnal Pembelajaran Matematika Inovatif), 4(3), 709-718. https://doi.org/10.22460/jpmi.v4i3.709-718

Fauzi, I., \& Arisetyawan, A. (2020). Analisis Kesulitan Belajar Siswa pada Materi Geometri Di Sekolah Dasar. Kreano, Jurnal Matematika Kreatif-Inovatif, 11(1), 27-35. https://doi.org/10.15294/kreano.v11i1.20726

Happy, N., Faiqotun Alfin, Z., \& Handayanto, A. (2019). Analisis Kesalahan Siswa Dengan Gaya Kognitiff Reflektif Pada Materi Segiempat Berdasarkan Newman'S Error Analysis (Nea). FIBONACCI: Jurnal Pendidikan Matematika Dan Matematika, 5(2), 129. https://doi.org/10.24853/fbc.5.2.129-140

Hariyani, S., Aisyah, F. N. K., \& Dinullah, R. N. I. (2019). Analisis Kesalahan Penyelesaian Soal Cerita Berdasarkan Kriteria Watson. Jurnal Review Pembelajaran Matematika, 4(1), 11-22. https://doi.org/10.15642/jrpm.2019.4.1.11-22

Muhassanah, N., Sujadi, I., \& Riyadi. (2014). Analisis Keterampilan Geometri Siswa Dalam Memecahkan Masalah Geometri Berdasarkan Tingkat Berpikir Van Hiele. Jurnal Elektronik Pembelajaran Matematika, 2(1), 54-66. http://jurnal.fkip.uns.ac.id

Nurhasanah, F., Kusumah, Y. S., \& Sabandar, J. (2017). Concept of Triangle: Examples of Mathematical. International Journal on Emerging Mathematics Education, 1(1), 53-70.

Sanwidi, A. (2018). Analisisi Kesalahan Mahasiswa Matematika Unu Blitar Dalam Menyelesaikan Soal Matematika Materi Fungsi Berdasarkan Kriteria Watson. Briliant: Jurnal Riset Dan Konseptual, 3(1), 128. https://doi.org/10.28926/briliant.v3i1.138

Saputri, R., Sugiarti, T., Murtikusuma, R., Trapsilasiwi, D., \& Yudianto, E. (2018). Analisis Kesalahan Siswa dalam Menyelesaikan Soal Materi Fungsi Berdasarkan Kriteria Watson Ditinjau dari Perbedaan Gender Siswa SMP Kelas VIII. Kadikma, 9(2), 59-68.

Siagian, P. P. G., \& Sinaga, B. (2019). Analysis of Difficulty of student' s Geometry on Van Hiele' s Thinking Theory. International Journal on Emerging Mathematics Education, 3(2), 162-176.

Smith, J. P., van den Heuvel-Panhuizen, M., \& Teppo, A. R. (2011). Learning, teaching, and using measurement: Introduction to the issue. ZDM - International Journal on Mathematics Education, 43(5), 617-620. https://doi.org/10.1007/s11858-011-0369-7 